\title{
Oxidative metabolism and muscle biochemical profile of polo horses supplemented with an ADE vitamin complex ${ }^{1}$
}

\author{
Rebeca A. Weigel ${ }^{2}$, Alessandra Silva Lima², Aline Alberti Morgado², Giovanna Rocha \\ Nunes $^{2}$, Maurício M. Miriam ${ }^{2}$, Stefano F. Hagen ${ }^{3}$, Wilson R. Fernandes ${ }^{2}$ \\ and Maria C.A. Sucupira ${ }^{2 *}$
}

\begin{abstract}
Weigel R.A., Lima A.S., Morgado A.A., Nunes G.R., Mirian M.M., Hagen S.F., Fernandes W.R. \& Sucupira M.C.A. 2013. Oxidative metabolism and muscle biochemical profile of polo horses supplemented with an ADE vitamin complex. Pesquisa Veterinária Brasileira 33(Supl.1):58-62. Departamento de Clínica Médica, Faculdade de Medicina Veterinária e Zootecnia, Universidade de São Paulo, Av. Prof. Dr. Orlando M. de Paiva 87, São Paulo, SP 05508 270, Brazil. E-mail: msucupir@usp.br

Horses used for the game of polo experience abrupt and frequent changes in exercise intensity. To meet this variable energy demand, the horses use both aerobic and anaerobic pathways in varying proportions and intensities. In this context, there must be a balance between the formation of reactive oxygen species (ROS) and the action of antioxidants to prevent oxidative stress and its consequences. The effect of supplementation with an ADE vitamin complex on oxidative metabolism was evaluated in 18 crossbred horses randomly divided between a treated group (TG) and a control group (CG). The TG animals received the ADE vitamin complex ( $1 \mathrm{~mL} / 50 \mathrm{~kg}$ of body weight) by deep intramuscular injection at 30 and 15 days before the game. The CG horses received $10 \mathrm{ml}$ of saline by the same administration route and schedule. During the polo match, the animals played for a total of 7.5 min. Blood samples were collected on the same days as the treatments were administered, and immediately before and at 15, 90 and 180 minutes after the game. The concentrations of creatine phosphokinase (CK), lactate dehydrogenase (LDH), lactate, glucose, aspartate aminotransferase (AST), glutathione (GSH), superoxide dismutase (SOD) and malondialdehyde (MDA) were measured in the blood samples. After the game, the TG demonstrated higher levels of AST, lactate and glucose than the CG, suggesting more efficient energy use by the treated animals. The higher GSH and lower lactate levels in the TG before the game suggest the presence of a greater antioxidant supply in the treated animals. The maintenance of the MDA levels indicates that neither of the groups exhibited oxidative stress.
\end{abstract}

INDEX TERMS: ADE vitamin complex, oxidative metabolism, muscle biochemical profile, polo, Equidae.

RESUMO.- [Metabolismo oxidativo e perfil bioquímico muscular de cavalos de pólo suplementados com complexo vitamínico ADE.] O jogo de pólo se caracteriza por mudanças abruptas e frequentes na intensidade

\footnotetext{
${ }^{1}$ Received on October 29, 2013.

Accepted for publication on November 27, 2013.

${ }^{2}$ Departamento de Clínica Médica, Faculdade de Medicina Veterinária e Zootecnia (FMVZ), Universidade de São Paulo (USP), Av. Prof. Dr. Orlando Marques Paiva 87. Cidade Universitária, São Paulo, SP 05508-270, Brazil. E-mails: rebec@usp.br, alessandralima@usp.br, aline.morgado@ usp.br, giovannarocha@hotmail.com, hagen@usp.br, wilsonrf@usp.br, msucupir@usp.br; *Corresponding author: msucupir@usp.br
}

do exercício dos cavalos. Para satisfazer esta demanda inconstante de energia, os animais utilizam as vias aeróbia e anaeróbia em proporções e intensidade variáveis. Neste contexto deve haver equilíbrio entre a formação das espécies reativas de oxigênio (EROs) e a ação das substâncias antioxidantes a fim de evitar o estresse oxidativo e suas consequências. Avaliou-se o efeito da suplementação com vitaminas ADE no metabolismo oxidativo destes animais. Para tanto, 18 equinos mestiços foram distribuídos aleatoriamente em dois grupos: tratado e controle (GT) e controle (GC).Os animais do GT receberam complexo vitamínico ADE $(1 \mathrm{~mL} / 50 \mathrm{~kg}$ de peso vivo) pela via intramuscular 
profunda aos 30 e 15 dias antes do jogo. Os cavalos do GC receberam, pela mesma via de administração e nos mesmos momentos, $10 \mathrm{~mL}$ de solução fisiológica. Os animais jogaram um tempo de 7,5min. Foram coletadas amostras de sangue nos mesmos dias de tratamento e imediatamente antes e aos 15, 90 e 180 minutos após o jogo. Foram determinadas as concentrações sanguíneas de CK, LDH, lactato, glicose, AST, GSH, SOD e MDA. Após o jogo o GT apresentou maiores valores para AST, lactato e glicemia que o GC, sugerindo melhor aproveitamento energético dos animais tratados. Os valores maiores de GSH e menores de lactato no GT antes da prova sugerem maior aporte antioxidante nos animais tratados. A manutenção dos teores de MDA indica que nenhum dos grupos entrou em estresse oxidativo.

TERMOS DE INDEXAÇÃO: Vitaminas ADE, metabolismo oxidativo, polo, equinos.

\section{INTRODUCTION}

Equestrian polo is a notably old sport, with historical references indicating its creation by knights and hunters of Central Asia circa 600 BC. From that era, Englishmen began to spread the sport throughout the world from Asia to Europe. English nationals brought the sport of polo to Brazil in 1930, when they came to build the national railroad. In subsequent years, Brazilian polo has been growing in ter$\mathrm{ms}$ of the quality and the number of players and animals (Brandão 1992). Although polo is a widespread sport, studies related to the metabolic profile of polo horses are still scarce, especially in Brazil.

Polo is played on a flat, grassy field measuring 275x180m (Polo Federation of São Paulo [Federação Paulista de Pólo - FPP\}/Bazilian Polo Confederation [Confederação Brasileira de Pólo - CBP], 2012), and each team has 4 sets of horses and riders. A match is composed of up to 8 chukkas, which are periods lasting $7.5 \mathrm{~min}$ each. The same horse may only be used in 2 periods (FPP/BCP, 2012). The polo game requires constant changes in the rhythm of the animal's exercise with alternations between fast gallops, sudden stops and turns. During a match, the animals use aerobic and anaerobic pathways to generate muscle energy (Zobba et al. 2011). The effort exerted during exercise is usually evaluated with a focus on the muscular and energetic metabolism. Although interest in the oxidative metabolism of both human and animal athletes has increased, few studies have assessed the metabolic dynamics in national conditions of polo horses.

The formation of reactive oxygen species (ROS) is physiological, and the antioxidant systems of healthy organisms can maintain the oxidative balance effectively. However, horses used for sports involving explosive activity are more prone to oxidative stress because the formation of ROS during exercise is increased by the higher rate of mitochondrial respiration associated with greater energetic demands (Moffarts et al. 2005). Human athletes consume oxygen at a rate of $70 \mathrm{~mL} / \mathrm{kg} / \mathrm{min}$, while horses can consume oxygen at a rate of $200 \mathrm{~mL} / \mathrm{kg} / \mathrm{min}$. These data suggest that horses are at risk of oxidative stress during exercise
(Kinnunen et al. 2005). Skeletal muscle may be especially susceptible to oxidative damage, as it seems to have lower levels of antioxidants than do other tissues (Avellini et al. 1999). Although it is clear that equine athletes exhibit a high demand for antioxidants, the benefit of vitamin supplementation on the metabolism of these animals is not thoroughly understood.

The aim of this study was to evaluate the effect of supplementation with the ADE vitamin complex on the oxidative metabolism of horses subjected to physical exertion during equestrian polo matches.

\section{MATERIALS AND METHODS}

This study was conducted during January of 2009 in the city of Indaiatuba, São Paulo. A total of 18 crossbred, healthy horses trained for equestrian polo were used, including 7 females and 11 males, with an average weight of $464( \pm 21) \mathrm{kg}$ and an average age of $6.9( \pm 1.7)$ years. The animals were kept in individual stalls and received $8 \mathrm{~kg}$ of coast-cross hay and commercial concentrate at $1 \%$ of the body weight (Guabi Equitage Polo ${ }^{\circledR}$ ) divided into 2 daily meals that provided 6750 IU of vitamin A, 1485 IU of vitamin D and 180 IU of vitamin E per kg of concentrate.

The polo match was held in an open field in the morning at an average temperature of $26.3^{\circ} \mathrm{C}$ and a humidity of $72 \%$ (Matsuo 2012). The animals were randomly divided into 2 groups, the treated group (TG) and the control group (CG), and each animal played for only 1 period lasting $7.5 \mathrm{~min}$. The TG received a dose of $1 \mathrm{~mL} / 50 \mathrm{~kg}$ of live weight $(270,000 \mathrm{IU}$ of vitamin A, 80,000 IU of vitamin $\mathrm{D}$ and $80 \mathrm{IU}$ of vitamin $\mathrm{E} / \mathrm{mL}$ of product) of the ADE vitamin complex via deep intramuscular injection at 30 and 15 days before the game. The CG received $10 \mathrm{~mL}$ of saline by the same route and schedule.

The serum samples were collected 30 days before the game (M0), immediately prior to the first dose (M1), 15 days before the event, prior to the second dose (M2), moments before the game (M3), 15 minutes after the game (M4), 90 minutes after the game (M5) and 180 minutes after the game. The concentrations of glucose (commercial kit, Sigma 318-100), lactate L (commercial kit, Kovalent $1100250 \mathrm{~K}$ ), aspartate aminotransferase (AST; commercial kit, Biosystems 11,531), creatine phosphokinase (CK; commercial kit, Biosystems 11,524) and lactate dehydrogenase (LDH; commercial kit, DiaSys/Bioexpress 142019910021) were analyzed in the fluoride-stabilized plasma with an automatic biochemical analyzer (Labtest brand, model Labmax 240). The levels of malondialdehyde (MDA) were measured in the heparinized plasma according to the method of Esterbauer and Cheeseman (1990). The concentrations of reduced glutathione (GSH) were measured in the whole blood according to Beutler et al. (1963). The concentrations of superoxide dismutase (SOD) were analyzed in erythrocytes using a colorimetric method described by Woolliams and Wiener (1983) and adapted for the automatic biochemical analyzer with a commercial RANDOX® kit (SD125).

The data distribution was verified by the Kolmogorov-Smirnov test. The data with a parametric distribution were subjected to analysis of variance (one-way ANOVA) and Tukey's test. The data with a non-parametric distribution were analyzed with the Mann-Whitney test. P-values less than 0.05 were considered significant. The results were expressed as the mean +/- the standard deviation for the data with a parametric distribution or as median, minimum and maximum values for the data with a nonparametric distribution. The tests were performed using MINITAB $®$ statistical software, version 14.1 (Minitab Inc. State College, Pennsylvania, USA). 


\section{RESULTS}

None of the horses showed local or systemic clinical reactions to the supplement. All of the animals in the study played for 1 period and exhibited no clinical signs of fatigue or rhabdomyolysis.

There were no differences in the levels of AST, CK, LDH or glucose between the treatment groups (Table 1, Fig.1). The CG exhibited higher concentrations of lactate than the $\mathrm{TG}$ at M2. When considering the different time points, the blood glucose levels were higher at M3 than at M0 and M5 only in the CG and remained stable in the TG. The lactate levels were higher at M3 than at the other time points only in the CG. The LDH levels of the TG were lower at M0 than at the other time points, while there were no differences between the time points in the CG.

The SOD and MDA levels did not differ between the groups or time points. At M1, the GSH levels were higher in the CG than in the TG. When the time points were com- pared, higher concentrations of GSH were observed at M3 than at M0 only in the CG (Table 1, Fig.2).

\section{DISCUSSION}

In Brazil, equestrian polo is played on open fields, usually during the day, and the beginning of training generally coincides with the beginning of the year. Before the initiation of the study, the horses were at rest for 30 days, during which time they remained loose in paddocks with optimal forage pasture. At the beginning of the experiment, the horses were returned to the stalls and began receiving concentrated food and hay, and training began 30 days after the first dose of the vitamin supplement was given. Therefore, the animals did not train for 60 days.

When the effect of exercise was considered alone without taking the treatment into account, the biochemical variables and the average blood glucose levels were similar to those found by Ferraz et al. (2010), who also worked

Table 1. Mean values, standard deviations and median, minimum, maximum and P-values of metabolic and oxidative variables of equestrian polo horses divided into groups treated with the ADE vitamin complex (TG) or a control group (CG)

\begin{tabular}{|c|c|c|c|c|c|c|c|c|c|}
\hline & & & M0 & M1 & M2 & M3 & M4 & M5 & $\mathrm{P}$ \\
\hline \multirow{5}{*}{ AST } & $\mathrm{CG}$ & Média & $177.94^{\mathrm{b}}$ & $176.06^{b}$ & $178.10^{\mathrm{b}}$ & $215.23^{a}$ & $193.58^{\mathrm{ab}}$ & $188.51^{\mathrm{ab}}$ & 0.01 \\
\hline & & DP & $(17.86)$ & $(24.24)$ & (19.33) & $(30.72)$ & $(22.56)$ & (21.39) & \\
\hline & TG & Média & 172.91 & 164.91 & 185.81 & 208.07 & 194.03 & 191.8 & 0.34 \\
\hline & & DP & $(24.42)$ & $(30.03)$ & (51.04) & (43.51) & $(45.96)$ & (43.94) & \\
\hline & & $\mathrm{P}$ & 0.78 & 0.42 & 0.66 & 0.63 & 0.96 & 0.96 & \\
\hline \multirow{5}{*}{ CK } & CG & Média & $162.67^{\mathrm{A}}$ & 183.22 & 139.63 & 159.81 & 184.43 & 184.78 & 0.49 \\
\hline & & DP & $(44.95)$ & $(54.62)$ & (49.18) & $(51.70)$ & (54.26) & $(60.52)$ & \\
\hline & $\mathrm{TG}$ & Média & $121.43^{\mathrm{B}}$ & 161.34 & 163.77 & 171.76 & 179.22 & 181.48 & 0.06 \\
\hline & & DP & (29.89) & (51.36) & (38.51) & (37.81) & $(46.00)$ & (37.63) & \\
\hline & & $\mathrm{P}$ & 0.05 & 0.42 & 0.29 & 0.38 & 0.84 & 0.9 & \\
\hline \multirow{5}{*}{ Glucose } & CG & Média & $4.43^{b}$ & $4.49^{\mathrm{ab}}$ & $4.65^{\mathrm{ab}}$ & $5.54^{\mathrm{a}}$ & $4.82^{\mathrm{ab}}$ & $4.3^{4 \mathrm{~b}}$ & 0.01 \\
\hline & & DP & $(0.42)$ & $(0.29)$ & $(0.96)$ & (1.05) & $(0.24)$ & $(0.46)$ & \\
\hline & TG & Média & 4.86 & 4.56 & 4.61 & 5.09 & 4.67 & 4.38 & 0.42 \\
\hline & & DP & (1.05) & $(0.52)$ & $(0.65)$ & $(0.86)$ & $(0.39)$ & $(0.47)$ & \\
\hline & & $\mathrm{P}$ & 0.31 & 0.74 & 0.93 & 0.37 & 0.36 & 0.87 & \\
\hline \multirow{5}{*}{ Lactate } & CG & Média & $0.75^{\mathrm{b}}$ & $0.83^{\mathrm{b}}$ & $1.79^{\mathrm{b}}$ & $15.13^{\text {Aa }}$ & $2.20^{\mathrm{b}}$ & $0.99^{\mathrm{b}}$ & 0.00 \\
\hline & & DP & (0.13) & $(0.13)$ & (2.78) & (8.44) & (1.83) & $(0.42)$ & \\
\hline & TG & Média & $0.82^{\mathrm{b}}$ & $0.74^{\mathrm{b}}$ & $0.80^{\mathrm{b}}$ & $4.57^{\mathrm{Ba}}$ & $1.13^{\mathrm{b}}$ & $0.90^{\mathrm{b}}$ & 0.00 \\
\hline & & DP & $(0.23)$ & $(0.16)$ & $(0.20)$ & (3.97) & $(0.30)$ & $(0.26)$ & \\
\hline & & $\mathrm{P}$ & 0.48 & 0.20 & 0.33 & 0.01 & 0.12 & 0.61 & \\
\hline \multirow{4}{*}{ LDH } & $\mathrm{CG}$ & Média & $492.84^{\mathrm{A}}$ & 613.92 & 548.90 & 623.10 & 569.64 & 511.72 & 0.08 \\
\hline & & DP & (66.98) & $(100.60)$ & (96.46) & (121.01) & (117.98) & (100.38) & \\
\hline & $\mathrm{TG}$ & Média & $373.12^{\mathrm{Bb}}$ & $660.87^{a}$ & $663.69^{a}$ & $690.49^{a}$ & $681.31^{\mathrm{a}}$ & $636.29^{a}$ & 0.00 \\
\hline & & DP & (76. & (149 & $(168$ & $(124$ & $(171$ & (142.71) & \\
\hline \multirow{6}{*}{ GSH } & & P & 0.0 & 0.47 & 0.1 & 0.29 & 0.15 & 0.06 & \\
\hline & $\mathrm{CG}$ & Média & $21.81^{\mathrm{b}}$ & $26.21 \mathrm{~A}^{\mathrm{ab}}$ & $25.08^{\mathrm{ab}}$ & $31.81^{\mathrm{a}}$ & $27.09^{\mathrm{ab}}$ & $27.30^{\mathrm{ab}}$ & 0.05 \\
\hline & & DP & $(8.50)$ & $(4.42)$ & (5.04) & (6.99) & $(6.00)$ & $(4.56)$ & \\
\hline & $\mathrm{TG}$ & Média & 23.66 & $16.58^{\mathrm{B}}$ & 26.37 & 27.62 & 23.69 & 22.45 & 0.15 \\
\hline & & DP & (11.85) & (5.92) & (6.27) & (7.23) & (9.47) & (7.65) & \\
\hline & & $\mathrm{P}$ & 0.73 & 0.00 & 0.66 & 0.26 & 0.40 & 0.08 & \\
\hline \multirow{5}{*}{ MDA } & CG & Mediana & 0.30 & 0.36 & 0.33 & 0.44 & 0.52 & 0.35 & $>0.19$ \\
\hline & & $\min / \max$ & $(0.15-0.89)$ & $(0.10-1.02)$ & $(0.17-1.88)$ & $(0.07-1.73)$ & $(0.07-0.95)$ & $(0.11-0.77)$ & \\
\hline & TG & Mediana & 0.35 & 0.30 & 0.36 & 0.36 & 0.21 & 0.34 & $>0.46$ \\
\hline & & $\min / \max$ & $(0.18-0.71)$ & $(0.05-0.52)$ & $(0.22-0.58)$ & (0.13-0.92) & $(0.17-0.71)$ & $(0.17-0.44)$ & \\
\hline & & $\mathrm{P}$ & 0.19 & 0.83 & 0.89 & 0.57 & 0.38 & 0.57 & \\
\hline \multirow{5}{*}{ SOD } & CG & Média & 2532.96 & 2934.81 & 2795.91 & 3102.09 & 2792.32 & 2756.82 & 0.59 \\
\hline & & DP & $(304.75)$ & $(422.06)$ & $(1260.20)$ & (1406.07) & (530.39) & (550.59) & \\
\hline & $\mathrm{TG}$ & Média & 2389.80 & 2459.57 & 3262.08 & 3218.98 & 2985.68 & 3081.10 & 0.24 \\
\hline & & DP & (698.32) & (594.41) & $(527.60)$ & (707.56) & (558.53) & $(545.94)$ & \\
\hline & & $\mathrm{P}$ & 0.64 & 0.50 & 0.26 & 0.84 & 0.24 & 0.16 & \\
\hline
\end{tabular}

Uppercase letters represent differences between treatments, and lowercase letters represent differences between time points within the group. 


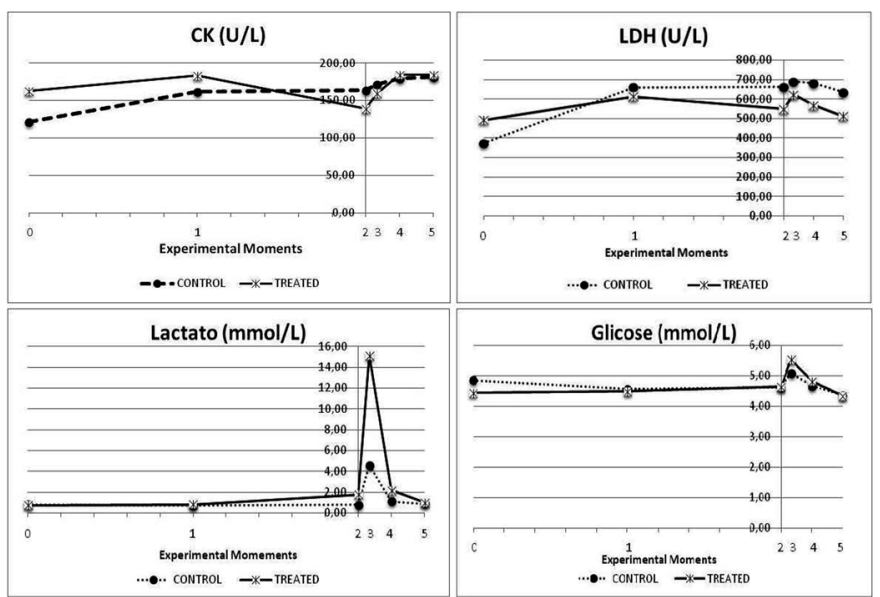

Fig.1. Means and standard deviations of the metabolic variables $\mathrm{CK}, \mathrm{LDH}$, lactate and glucose in equestrian polo horses divided into a group treated with the ADE vitamin complex (TG) and a control group (CG).

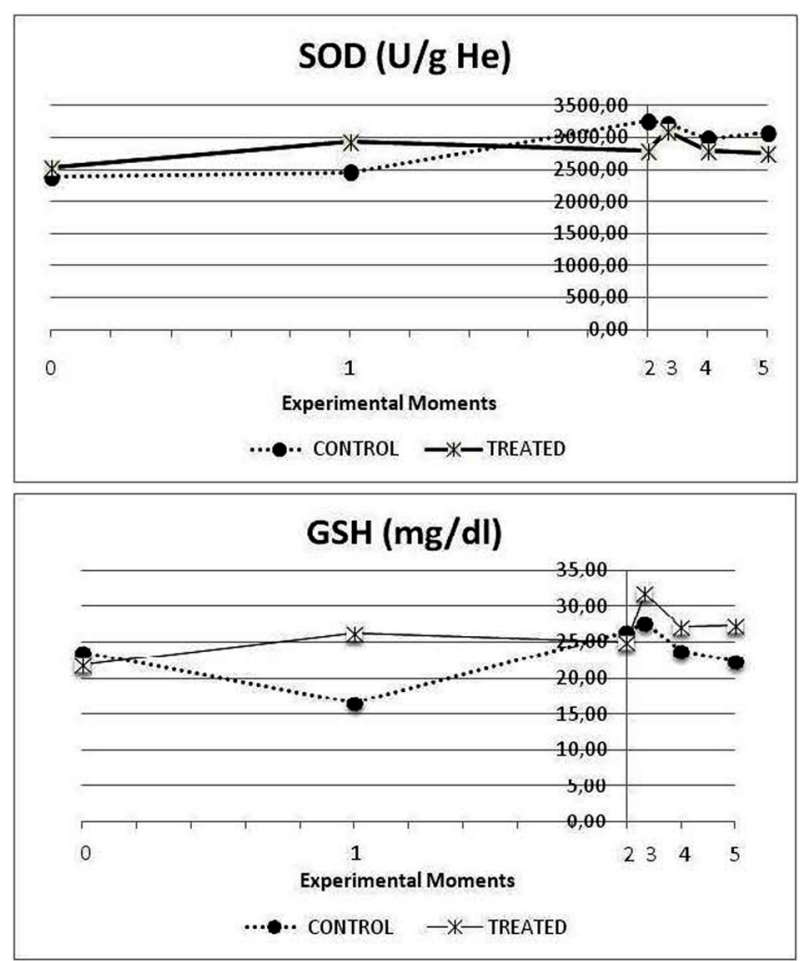

Fig.2. Means and standard deviations for the oxidative variables GSH and SOD in equestrian polo horses divided into a group treated with the ADE vitamin complex (TG) and a control group (CG).

with polo horses in the region of Indaiatuba and evaluated the effect of exercise on biochemical parameters, particularly the ion concentrations. Vieira (2011) observed similar variations in the levels of LDH and AST when studying polo horses in the city of Rio de Janeiro. The variation of lactate was similar in all 3 studies.

Measuring the enzyme activities of AST, CK and LDH is recommended for the evaluation of the equine muscle response during exercise (Thomassian et al. 2007). In the present study, the concentrations of these variables remained low, which suggests that the intensity of the exercise was low or that the animals maintained their physical conditioning even after a 60-day rest period.

Physical fitness leads to the decreased activity of glycolytic enzymes and to lower lactic acid production (Baker et al. 1998); accordingly, the lactate levels in trained animals are reduced more quickly after exertion. A study in racehorses revealed that lactate levels return to baseline within 2 hours after a race, demonstrating the excellent physical condition of these animals (Camargos et al. 2006). In the present study, although the lactate values of the CG immediately after the match were higher than those considered normal for the species ( 0.44 to $4.88 \mathrm{mmol} / \mathrm{L}$; Radostits et al. 2002), these levels returned to baseline after $90 \mathrm{~min}$ in both groups, which attests to the prime physical condition of these athletes, despite the rest period. Duncan and Prase (1986) considered the enzyme CK the most sensitive and specific indicator to identify and monitor muscle injury in horses. More recently, Rivero \& Piercy (2008) suggested that in addition to the clinical manifestation, the predisposition to rhabdomyolysis caused by exercise could be classified as follows: the animals exhibiting AST levels between 200 and $400 \mathrm{IU} / \mathrm{L}$ and CK levels between 50 and $200 \mathrm{IU} / \mathrm{L}$ are given a grade of 0 ; animals at grade 1 , or moderate, exhibit AST levels between 400 and $1200 \mathrm{IU} / \mathrm{L}$ and CK levels between 200 and $1000 \mathrm{IU} / \mathrm{L}$; and animals at grade 3, or severe, exhibit AST levels greater than $1200 \mathrm{IU} / \mathrm{L}$ and CK levels greater than $1000 \mathrm{IU} / \mathrm{L}$. Based on this classification, the animals in this study were classified as grade 0 (not predisposed).

The dynamics of the enzyme AST in the present study were quite similar between the 2 groups, as were the dynamics of $\mathrm{CK}$, which only showed a difference between the groups at M0. At this time point, the animals were returning from the rest period and had not yet received the supplement. This difference in the CK levels was not present 15 days later at M1 after the animals had received a dose of the supplement. Shortly after the game, the CG showed higher levels of AST, lactate and blood glucose. These results suggest the better use of energy during exercise by the TG. When there are low mitochondrial oxygen levels in the muscle during physical exercise, glucose/glycogen degradation occurs, thereby producing lactate. However, changes in lactate levels are not exclusively related to this mechanism, as other factors, such as a high-glucose diet, may influence the serum lactate levels (Bertuzzi et al. 2009). In the present study, this factor was neutralized because the animals were fed the same diet. It has been proposed that during periods of exertion, the interaction of multiple biochemical events and increased mitochondrial activity reduces the mitochondria's ability to oxidize all of the pyruvates produced by an oxidation step that normally leads to the conversion of pyruvates to lactate by the enzyme LDH (Gladden 2004, Robergs 2004).

The high oxygen consumption by mitochondria during intense muscle contraction increases ROS production in skeletal muscle (Silveira 2004). The ROS superoxide has been described as a potent inhibitor of aconitase, an enzyme that contributes to the substrate input for the Krebs 
cycle. As a consequence of this inhibition, the availability of NADH and FADH2 for the mitochondrial electron transport chain is reduced, thereby compromising ATP synthesis (Silveira 2004). This mechanism may favor glycolytic activity and increase the production of lactate/H+. Other ROS, including $\mathrm{H}_{2} \mathrm{O}_{2}$, nitric oxide and peroxynitrite, are equally important and can also inhibit the activity of aconitase (Andersson et al. 1998). In addition, a study in mice with high muscle expression of SOD revealed that these animals exhibited a higher rate of glucose uptake during muscle contraction compared to the control group (Schrauwen et al. 2003). These results support the proposition that ROS significantly affect the regulation of glucose metabolism during intense muscular activity (Silveira et al. 2011).

No differences were observed in the concentrations of SOD between the 2 groups, most likely due to the greater coefficient of variation (CV) observed in the TG relative to the CG at M2 (39\% vs. $19 \%)$ and M3 (40\% vs. $23 \%)$. The GSH levels were significantly different only at M1, possibly also due to the greater CV in the TG than the CG, as the TG curve suggests that before the game, the animals were at a lower oxidative condition than the CG. These results suggest that animals of the TG could have a greater antioxidant supply than the CG, as they demonstrated lower levels of lactate and a greater GSH response before the game. During the present study, the concentrations of MDA did not change between the treatments and time points, indicating that the horses did not undergo oxidative stress and supporting the hypothesis that these animals are adapted to the imposed exercise.

\section{CONCLUSION}

In the present study, the horses showed no oxidative stress, although the differences found between the groups in the lactate, glucose and GSH levels demonstrated that the muscle metabolism during exercise was more efficient following supplementation with the ADE vitamin complex.

\section{REFERENCES}

Andersson U., Leighton B., Young M.E., Blomstrand E. \& Newsholme E.A. 1998. Inactivation of aconitase and oxoglutarate dehydrogenase in skeletal muscle in vitro by superoxide anions and/or nitric oxide. Biochem. Biophys. Res. Commun. 249(2):512-516.

Avellini L., Chiaradia E. \& Gaiti A. 1999. Effect of exercise training, selenium and vitamin $\mathrm{E}$ on some free radical scavengers in horses (Equus caballus). Comp. Biochem. Physiol. B, Biochem. Mol. Biol. 123(2):147154.

Baker S.K., Mccullagh K.J.A., Bonen A., Thomas C., Bishop D.J., Lambert K. \& Mercier J. 1998. Training intensity-dependent and tissue-specific increases in lactate uptake and MCT-1 in heart and muscle. J. Appl. Physiol. 84:987-994

Bertuzzi R.C.M., Silva A.E.L., Abad C.C.C. \& Pires F.O. 2009. Metabolismo do lactato: uma revisão sobre a bioenergética e a fadiga muscular lactate metabolism: a review on bioenergetics and muscle fatigue. Revta Bras. Cineantropometria e Desempenho Humano 11(2):226-234.
Beutler E., Duron 0. \& Kelly B.M. 1963. Improved method for the determination of blood glutatione. J. Lab. Clin. Med. 61(5):882-888.

Brandão I.L. 1992. Polo Brasil. Ed. Markimidia, São Paulo. 158p.

Camargos A.S., Costa A.P.D., Carvalho C.B., Pinheiro A.C.M., Guidi R.C. \& Souza D.R. 2006. Alterações nos valores de lactato sanguíneo em cavalos de corrida induzidas por páreos de 1300 mestros. Revta Univ. Rural, Série Ciências da Vida, Seropédica/RJ, 26:S.

Duncan J.R. \& Prase K.W. 1986. Veterinary Medicine Clinical Pathology. $2^{\text {nd }}$ ed., Iowa State University Press, Ames, p.175-179.

Estenbauer H. \& Cheeseman K.H. 1990. Determination of aldehydic lipid peroxidation products: malonaldeyde and 4-hydroxynonenal. Methods in Enzymology 186:407-421.

Ferraz G.C., Soares O.A.B., Foz N.S.B., Pereira M.C. \& Queiroz-Neto A. 2010. The workload and plasma ion concentration in a training match session of high-goal (elite) polo ponies. Equine Vet. J. S42(38):191-195.

FPP/CBP 2012. Regulamento de Polo. Federação Paulista de Polo e Confederação Brasileira de Polo, São Paulo.

Gladden L.B. 2004. Lactate metabolism: a new paradigm for the third millennium. J. Physiology 558:5-30.

Kinnunen S., Atalay M., Hyyppä S., Lehmuskero A., Hänninen O. \& Oksala N. 2005. Effect of prolonged exercise on oxidative stress and antioxidant defense in endurance horse. J. Sports Sci. Med. 4:415-421.

Moffarts B., Kirschvink N., Art T., Pincemail J. \& Lekeux P. 2005. Effect of oral antioxidant supplementation on blood antioxidant status in trained thoroughbred horses. Vet. journal 169(1): 65-74.

Matsuo M.P. 2012. Comunicação pessoal (Empresa Climatempo Assessoria e Consultoria Meteorologica Ltda).

Radostits O.M., Gay C.C. \& Blood D.C. 2002. Clínica Veterinária. 9a ed. Guanabara Koogan, Rio de Janeiro. 1737p.

Rivero J.L.L. \& Piercy J. 2008. Prevalence and clinical management of equine exertional rhabdomyolysis syndrome in different types of sport horses. Proc. Conference on Equine Sports Medicine and Science. A. Lindner, Wageningen Academic Publishers, Wageningen, Netherlands, p.81-90.

Robergs R.A., Ghiasvand F. \& Parker D. 2004. Biochemistry of exerciseinduced metabolic acidosis. Am. J. Physiol., Regulatory, Integrative and Comparative Physiology 287(3):R502-516.

Schrauwen P., Hoeks J., Schaart G., Kornips E., Binas B. \& Van de Vusse G.J. 2003. Uncoupling protein 3 as a mitochondrial fatty acid anion exporter. FASEB Journal 17:2272-2274.

Silveira L.R. 2004. Considerações críticas e metodológicas na determinação de espécies reativas de oxigênio e nitrogênio em células musculares durante contrações. Arqs Bras. Endocrinol. Metabolismo 48(6):812-822.

Silveira L.R., Pinheiro C.H.J., Zoppi C.C., Cirabara S.M., Vitzel K.F., Bassit R.A., Leandro C.G., Barbosa M.R., Sampaio I.H., Melo I.H.P., Fiamoncini J., Carneiro E.M. \& Curi R. 2011. Regulação do metabolismo de glicose e ácido graxo no músculo esquelético durante exercício físico. Arqs Bras. Endocrinol. Metabolismo 55(5):303-313.

Thomassian A., Alves A.L.G. \& Hussni C.A. 2007. Atividades séricas da aspartato aminotransferase, creatina quinase e lactato desidrogenase de eqüinos submetidos ao teste padrão de exercício progressivo em esteira. Braz. J. Vet. Res. Anim. Sci. 44(3):183-190.

Woolliams J.A., Wiener G., Anderson P.H. \& McMurray C.H. 1983. Improved method for the determination of blood glutathione. Res. Vet. Sci. 34:253256.

Zobba R., Ardu M., Niccolini S., Cubeddu F., Dimauro C., Bonelli P., Dedola C., Visco S. \& Parpaglia M.L.P. 2011. Physical, hematological, and biochemical responses to acute intense exercise in polo horses. J. Equine Vet. Sci. 31(9):542-548. 